\title{
Polyommatus fominae Stradomsky, 2005 and P. szabokyi Bálint, 1990 (Lepidoptera: Lycaenidae) - species having appeared due to hybridization of P. icarus (Rottemburg, 1775) and P. icadius (Groum-Grshimaïlo, 1890)
}

\section{Polyommatus fominae Stradomsky, 2005 и P. szabokyi Bálint, 1990 (Lepidoptera: Lycaenidae) - виды, произошедшие вследствие гибридизаџии P. icarus (Rottemburg, 1775) и P. icadius (Groum-Grshimaïlo, 1890)}

\author{
B.V. Stradomsky ${ }^{1}$, R.V. Yakovlev ${ }^{2}$ \\ Б.В. Страдомский ${ }^{1}$, Р.В. Яковлев
}

\footnotetext{
${ }^{1}$ Rostov branch of Russian Entomological Society, PO Box 3318, 344092 Rostov-na-Donu, Russia. E-mail: bvstr@yandex.ru

2 Altai State University, Lenina 61, 656049 Barnaul, Russia. E-mail: yakovlev_asu@mail.ru

${ }^{1}$ Ростовское отделение Русского энтомологического общества, а/я 3318, Ростов-на-Дону 344092, Россия.

2 Алтайский государственный университет, пр. Ленина 61, Барнаул 656049, Россия.
}

KEY WORDS: hybrid, fauna, entomology, Lepidoptera, Lycaenidae, Polyommatinae.

КЛЮЧЕВЫЕ СЛОВА: гибрид, фауна, энтомология, Lepidoptera, Lycaenidae, Polyommatinae.

ABSTRACT. Molecular-genetic study of blues Polyommatus fominae Stradomsky, 2005 and P. szabokyi Bálint, 1990 showed that they have the mitochondrial gene COI characteristic of $P$. icadius (Groum-Grshimaïlo, 1890). The nuclear gene ITS2 of all the studied $P$. fominae is identical to that of P. icarus (Rottemburg, 1775), the ITS2 in one specimen of $P$. szabokyi was characteristic of $P$. icarus, and in the other - to $P$. icadius. Basing on the external characters and the molecular-genetic data, it is supposed that the taxa $P$. fominae and $P$. szabokyi appeared as a result of hybridization of $P$. icarus and $P$. icadius.

How to cite this article: Stradomsky B.V., Yakovlev R.V. 2018. Polyommatus fominae Stradomsky, 2005 and P. szabokyi Bálint, 1990 (Lepidoptera: Lycaenidae) - species having appeared due to hybridization of $P$. icarus (Rottemburg, 1775) and P. icadius (GroumGrshimaillo, 1890) // Russian Entomol. J. Vol.27. No.1. P.51-54. doi: 10.15298/rusentj.27.1.08

РЕЗЮМЕ. Молекулярно-генетические исследования голубянок Polyommatus fominae Stradomsky, 2005 и P. szabokyi Bálint, 1990 показали, что они имеют митохондриальный ген COI, характерный для P. icadius (Groum-Grshimaïlo, 1890). Ядерный ген ITS2 всех изученных экземпляров $P$. fominaе идентичен $P$. icarus (Rottemburg, 1775), a ITS2 у одного экземпляра $P$. szabokyi была свойственной для P. icarus, а у другого - для P. icadius. На основании внешних признаков и молекулярно-генетических данных, предполагается, что P. fominae и P. szabokyi возникли вследствие гибридизации $P$. icarus и $P$. icadius.

\section{Introduction}

In the three last decades three taxa of blues (Lepidoptera: Lycaenidae) have been described in the genus Polyommatus Latreille, 1804 from southern Mongolia and the North Caucasus: P. szabokyi Bálint, 1990 (type locality - "Mongolei, Bayan Chongor Berge, Ih-Bogd, Orog-Nuur"), P. elenae fominae Stradomsky, 2005 (type locality — Russia, Karachay-Cherkess Republic, MussaAchitara Mountains Range), and P. shchurovi Stradomsky, 2006 (type locality - Russia, Karachay-Cherkess Republic, Mussa-Achitara Mountains Range) [Bálint, 1990; Stradomsky, 2005, 2006]. The status of these taxa were subsequently reappraised. $P$. szabokyi was recognized only as a reduced subspecies, $P$. icarus szabokyi [Tshikolovets et al., 2009] with the comment "According to our best knowledge the phenotype szabokyi is unique, and can be considered as a distinct and isolated taxon. This phenotype is most probably the result of the extreme ecological conditions typifying the Ih-Bogd region where there are vast saline steppes in the lake bed. Somewhat similar situation can be observed in Turkestan where the dwarf phenotype represented by "Lycaena Icarus Rott. var turanica Heyne, 1895" (Male and female syntypes: "Tura") occurs in arid and warmer regions".

The sympatrically inhabiting taxa $P$. fominae and $P$. shchurovi based on the study of the mitochondrial DNA of the gene COI were synonymized and reassigned to $P$. icadius (type locality "Ferghana"), which has significant differences in the COI gene sequence from P. icarus [Vodolazhsky, Stradomsky, 2008]. The additional molecular-genetic studies of these taxa is bases for this work. 
Material and methods

New specimens of the taxon P. szabokyi-35 males, 12 females, from SW Mongolia, Gobi-Altai aimak, 62 km SSE Bugat, N slope of Adzh-Bogdo Range, ZoolonSuuzhijn-Bulag spring, $45^{\circ} 05^{\prime} 25^{\prime} \mathrm{N}, 94^{\circ} 48^{\prime} 05^{\prime} \mathrm{E}, \mathrm{h}=$ $1350 \mathrm{~m}, 28.06 .2017, \mathrm{R} . \mathrm{V}$. Yakovlev leg.), paratypes and additional specimens of $P$. fominae (Figs $1-5), P$. icarus

Table 1. List of material with voucher codes and GenBank accession numbers Таблица 1. Список экземпляров-ваучеров и номеров ГенБанка

\begin{tabular}{|c|c|c|c|c|}
\hline \multirow{2}{*}{$\begin{array}{c}\text { Taxon of } \\
\text { Poly- } \\
\text { ommatus }\end{array}$} & \multirow[t]{2}{*}{ Locality } & \multirow{2}{*}{$\begin{array}{l}\text { Voucher } \\
\text { No. }\end{array}$} & \multicolumn{2}{|c|}{$\begin{array}{c}\text { GenBank accession } \\
\text { numbers }\end{array}$} \\
\hline & & & COI & ITS2 \\
\hline amandus & Russia: Gonachkhir (1900 m), Karachay-Cherkessia & ILL170 & KF860851 & KF894393 \\
\hline icarus & Israel: Mt Hermon $(2050 \mathrm{~m})$ & DB08003 & GU244491 & GQ166170 \\
\hline icarus & Italy: near Trento $(500-700 \mathrm{~m})$ & ILL018 & EU597139 & GQ885163 \\
\hline icarus & Russia: Sochi $(100 \mathrm{~m})$ Krasnodar & ILL030 & FJ428821 & GQ885166 \\
\hline icarus & Russia: Nov. Chara, Chita & ILL043 & FJ428818 & GQ885161 \\
\hline icarus & Russia: Dugino, Azov, Rostov-on-Don & ILL041 & FJ428822 & GQ885165 \\
\hline icarus & Greece: Dodoni $(450 \mathrm{~m})$, near Igoumenista & ILL027 & FJ428819 & GQ885162 \\
\hline icarus & Russia: Zav`yalovsky, Udmurtia & ILL049 & FJ428825 & GQ885167 \\
\hline icarus & Russia: Belokalitvensky District, Rostov-on-Don & ILL054 & GQ885173 & GQ885164 \\
\hline icadius & Tajikistan: Lake Dunkeldyk (4100 m), S.-E. Pamir & ILL022 & EU597143 & GQ885159 \\
\hline icadius & Iran: Ambarkesh (2900 m), Qazvin & ILL071 & GQ885172 & GQ885160 \\
\hline icadius & Afghanistan: $10 \mathrm{~km}$ S.Bamian, $2800 \mathrm{~m}$ & ILL096 & JQ026942 & JQ026945 \\
\hline icadius & Kyrgyzstan: Ala-too & ILL259 & KX247291 & KX247293 \\
\hline fominae & Russia: Gonachkhir (1900 m), Karachaj-Cherkesia & ILL003 & EU597127 & MF872678 \\
\hline fominae & Russia: Mts. Mussa-Achitara $(2400 \mathrm{~m})$, Karachaj-Cherkesia & ILL005 & EU597129 & MF872679 \\
\hline fominae & Russia: Jamagat $(1500 \mathrm{~m})$, , Karachaj-Cherkesia & ILL281 & MF872681 & MF872680 \\
\hline szabokyi & Mongolia: Gobi-Altai aimak (1350 m) & ILL278 & MF803704 & MF803707 \\
\hline szabokyi & Mongolia: Gobi-Altai aimak $(1350 \mathrm{~m})$ & ILL279 & MF803705 & MF803708 \\
\hline
\end{tabular}

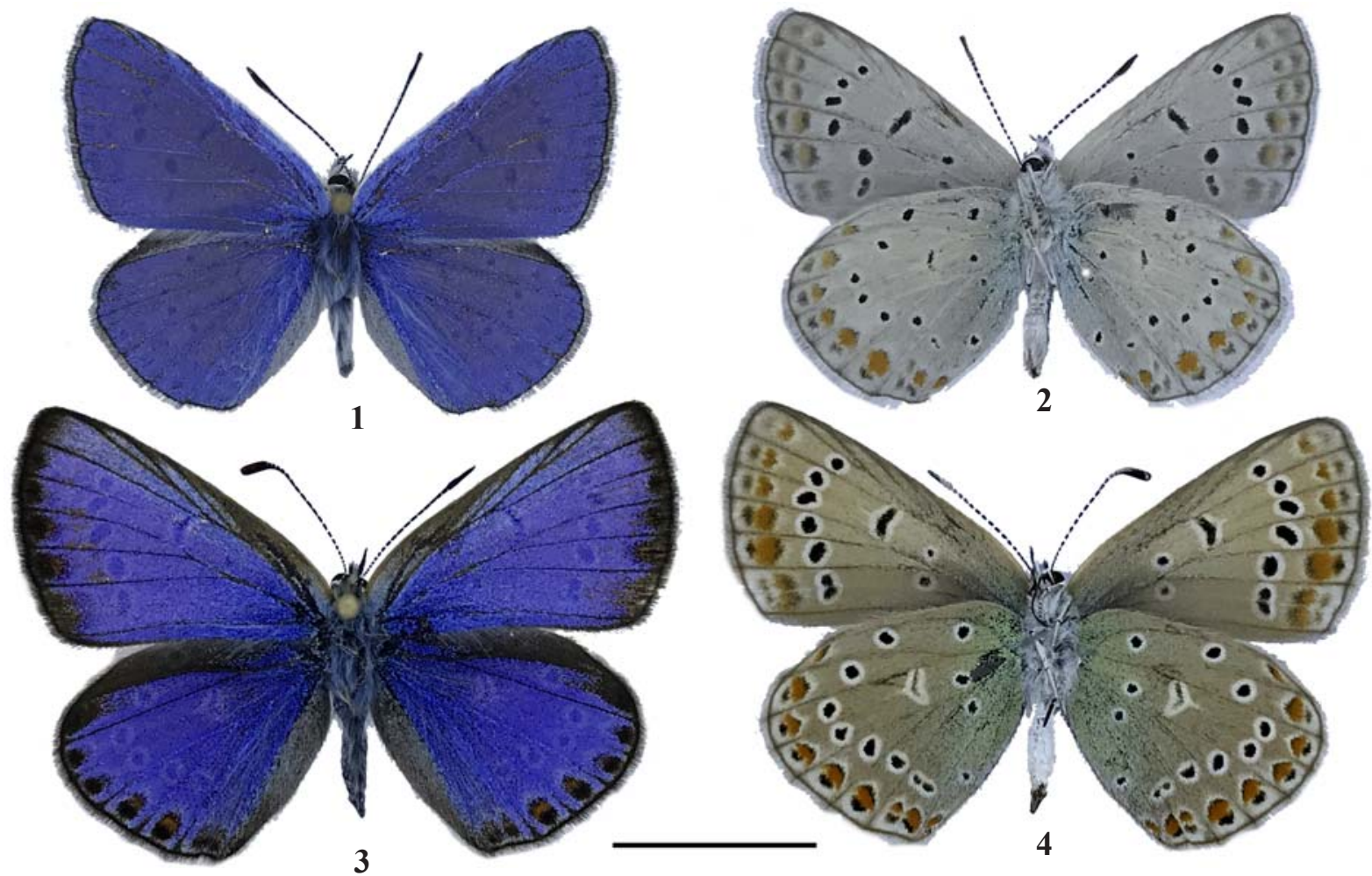

Figs 1-4. P. szabokyi Bálint, 1990, adult specimens from Zoolon-Suuzhijn-Bulag spring: 1-2 - male; 3-4 - female; 1, 3 - upperside; 2-4 - underside.

Рис. 1-4. P. szabokyi Bálint, 1990, имаго Zoolon-Suuzhijn-Bulag spring: 1-2 - самец; 3-4 - самка; 1, 3 - сверху; 2-4 - снизу. 
and P. icadius (Table 1) were sequenced in this study.

We amplified the DNA 5' section of the mitochondrial gene Cytochrome Oxidase subunit I (COI) and the nuclear non-coding sequence internal transcribed spacer 2 (ITS2) on the Mastercycler gradient (Eppendorf). The following cycling protocols were used: an initial $4 \mathrm{~min}$ denaturation at $95^{\circ} \mathrm{C}$ and 40 cycles of $30 \mathrm{~s}$ denaturation at $95^{\circ} \mathrm{C}, 30 \mathrm{~s}$ annealing at $53^{\circ} \mathrm{C}$ and $60 \mathrm{~s}$ extension at $72^{\circ} \mathrm{C}$.

We used the following PCR primer pairs: forward, 5'TAG CGA AAA TGA CTT TTT TCT A-3' with reverse, 5'-TTG CTC CAG CTA ATA CAG GTA A-3' were used to amplify COI. ITS2 was amplified with forward, 5'-GGG CCG GCT GTA TAA AAT CAT A-3' and reverse, 5'-AAA AAT TGA GGC AGA CGC GAT A-3' [Stradomsky, 2016].

The amplified fragments were separated using an automated sequencing machine (Applied Biosystems 3500). The analysis of primary nucleotide sequences was made with the application of BioEdit Sequence Align- ment Editor, version 7.0.5.3 [Hall, 1999].

COI and ITS2 nucleotide sequences were treated quantitatively using MEGA5 [Tamura et al., 2011] methods Maximum Likelihood (ML).

\section{Results}

The obtained results of molecular-genetic study are presented in the form of ME-cladograms of DNA sections for non-linked mitochondrial COI gene (Fig. 6) and nuclear sequence ITS2 (Fig. 7). The presented data show that both mitochondrial and nuclear DNA sequences in $P$. icarus and $P$. icadius form independent branches on cladograms. Additionally, both clades if $P$. icadius occur closer to the outgroup - P. amandus, which indicates a more ancient origin of the taxon $P$. icadius of a mountainous Central Asian origin. The placement location of $P$. fominae and $P$. szabokyi on the clades was unexpected. The COI gene of $P$. fominae is close to and may be
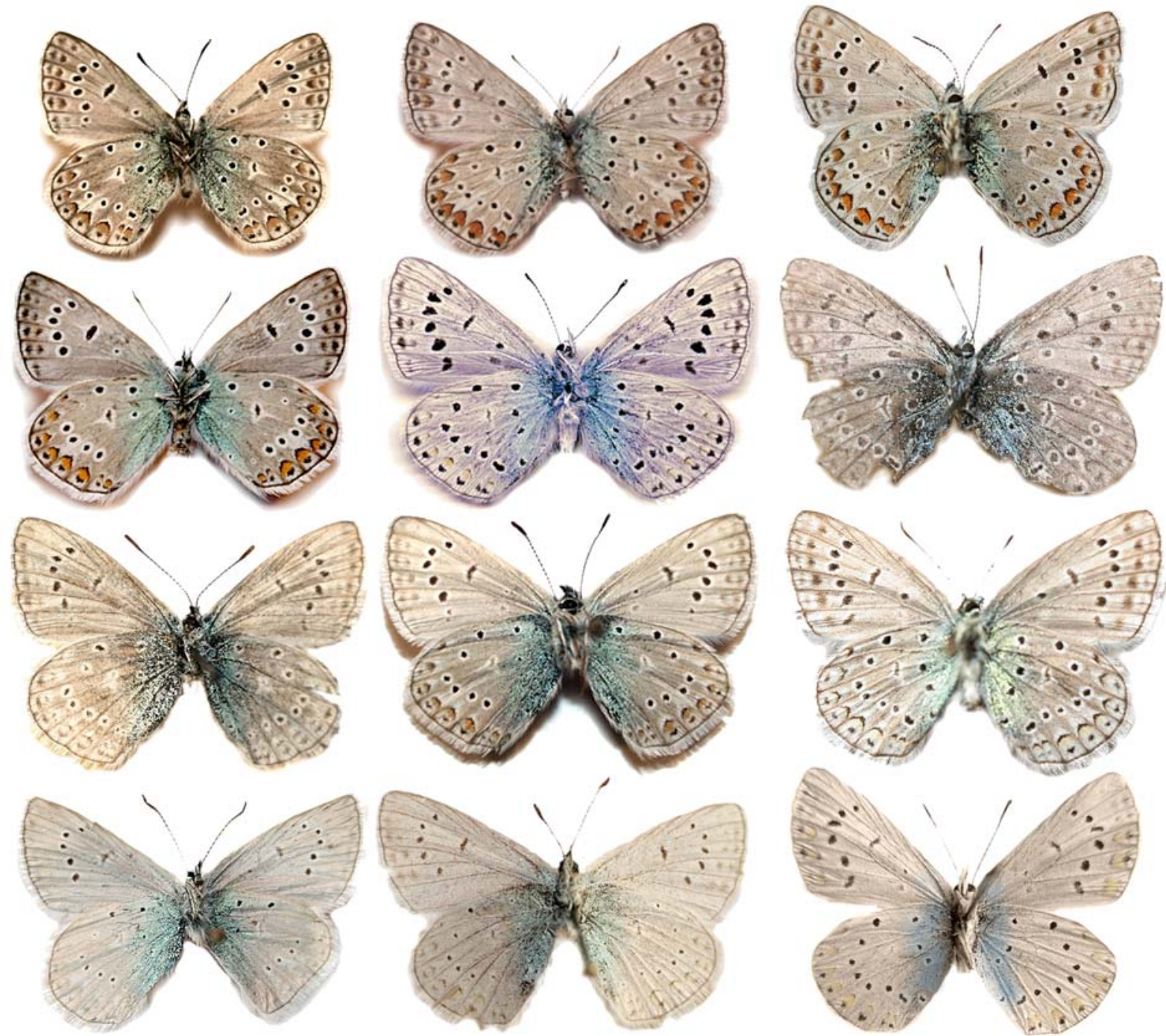

Fig. 5. Polyommatus spp., ventral view: icarus vouchers ILL018, ILL041, ILL043; fominae vouchers ILL003, ILL005, ILL281; icadius vouchers ILL259, ILL022, ILL071, ILL096; szabokyi vouchers ILL278, ILL279.

Рис. 5. Polyommatus spp., снизу: ваучеры icarus ILL018, ILL041, ILL043; ваучеры foтinae ILL003, ILL005, ILL281; ваучеры icadius ILL259, ILL022, ILL071, ILL096; ваучеры szabokyi ILL278, ILL279. 
identical to that of $P$. icadius. Similarly the nuclear sequences ITS 2 in all the studied $P$. fominae specimens were identical to $P$. icarus. For the P. szabokyi, the result was even more complex. Both examined specimens have, as well as $P$. fominae, the mitochondrial COI gene characteristic of $P$. icadius. The nuclear sequence ITS2 in one specimen was characteristic of $P$. icarus, in the other specimen of $P$. icadius.

\section{Discussion}

Our following hypotheses for the above results are that the archaic taxon of the mountainous Caucasus was $P$. icadius. Migrating males of a more recent taxon, $P$. icarus dispersed into new areas mating with females of the closely related species, $P$. icadius. The descendants of these hybrids had mitochondrial genes (including COI) of $P$. icadi$u s$. Further dispersals of males $P$. icarus did not change the haplotype of mitochondrial DNA but contributed to a gradual and complete replacement of nuclear DNA of $P$. icadius by DNA of $P$. icarus. This process resulted in the appearance of a hybrid taxon as $P$. fominae with mitochondrial gene of $P$. icadius and the nuclear one of $P$. icarus. Furthermore, the habitus of the $P$. fominae specimens widely varies from the typical to $P$. icarus (Fig.5, voucher ILL003) to the phenotype of $P$. icadius (Fig. 5, vouchers ILL005, ILL281), supporting a hybrid origin.

Apparently, a similar phenomenon may be the cause for the appearance of the P.szabokyi. This hybridization may have occurred at an earlier period with the presence of hybrids as respresented by the type of $P$. fominae. There are also specimens with the genomic characteristic of only $P$. icadius. The habitus of P. szabokyi-like specimens are similar to $P$. icadius, supporting a hy-

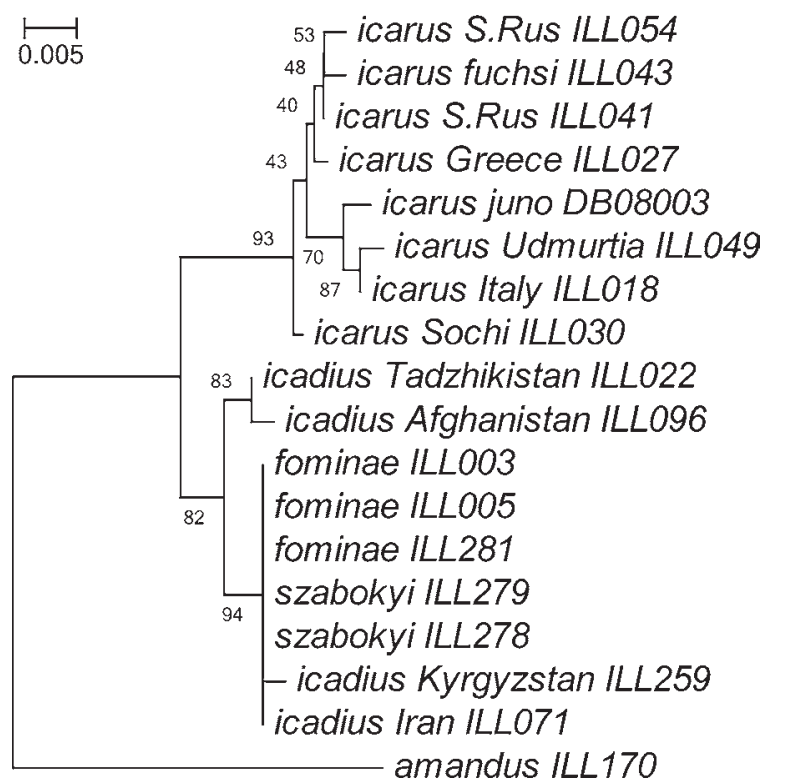

Fig. 6. Polyommatus spp.: ME-cladogram for COI DNA sequences

Рис. 6. Polyommatus spp.: кладограмма для COI ДНК сиквенсов. bridization process occurring during relatively recent times and is not yet complete.

ACKNOWLEDGMENTS. We express our gratitude to the colleagues for their assistance in the field studies on the territory of Caucasus (E.A. Fomina) and Mongolia (A. Fomichev, V. Rudoj, A. Cherepanov).The authors are grateful to Anna Ustjuzhanina (Tomsk, Russia) and Prof. Boris Kondratieff (Fort Collins, USA) for language improvements. The results were obtained within the framework of the state task No. 6.2884.2017/ 4.6 Ministry of Education and Science of Russian Federation.

\section{References}

Bálint Z. 1990. Neue Untersuchungen an Mongolischen Bläulingen — New investigations on Mongolian lycaenid butterflies (Lep., Lycaenidae). Lycaenidae of Mongolia VI // Galathea. Vol.6. No.1. P.1-16.

Hall T.A. 1999. BioEdit: a user-friendly biological sequence alignment editor and analysis program for Windows 95/98/NT // Nucleic Acids Symposium Series. Vol.41. P.95-98.

Stradomsky B.V. 2005. [A new subspecies of Polyommatus elena Stradomsky et Arzanov, 1999 (Lepidoptera: Lycaenidae) from the subalpine belt of West Caucasia] // Caucasian entomological bulletin. Vol.1. No.2. P.151-152 [in Russian].

Stradomsky B.V. 2006. [Polyommatus shchurovi sp.n. (Lepidoptera: Lycaenidae) from the altitude areas of Western Caucasus] // Caucasian entomological bulletin. Vol.2. No.2. P.215-217 [in Russian].

Stradomsky B.V. 2016. A molecular phylogeny of the subfamily Polyommatinae//Caucasian entomological bulletin. Vol.12. No.1. P.145-156.

Tamura K., Peterson D., Peterson N., Stecher G., Nei M., Kumar S. 2011. MEGA5: molecular evolutionary genetics analysis using maximum likelihood, evolutionary distance, and maximum parsimony methods // Molecular Biology end Evolution. Vol.28. P.2731-2739.

Tshikolovets V.V., Yakovlev R.V., Bálint Z. 2009. The Butterflies of Mongolia. Kyiv-Pardubice. 320 pp.

Vodolazhsky D.I., Stradomsky B.V. 2008. [Phylogenetic analysis of subgenus Polyommatus (s. str.) Latreille, 1804 (Lepidoptera: Lycaenidae) based on mtDNA markers. Part I] // Caucasian entomological bulletin. Vol.4. No.1. P.123-130 [in Russian].

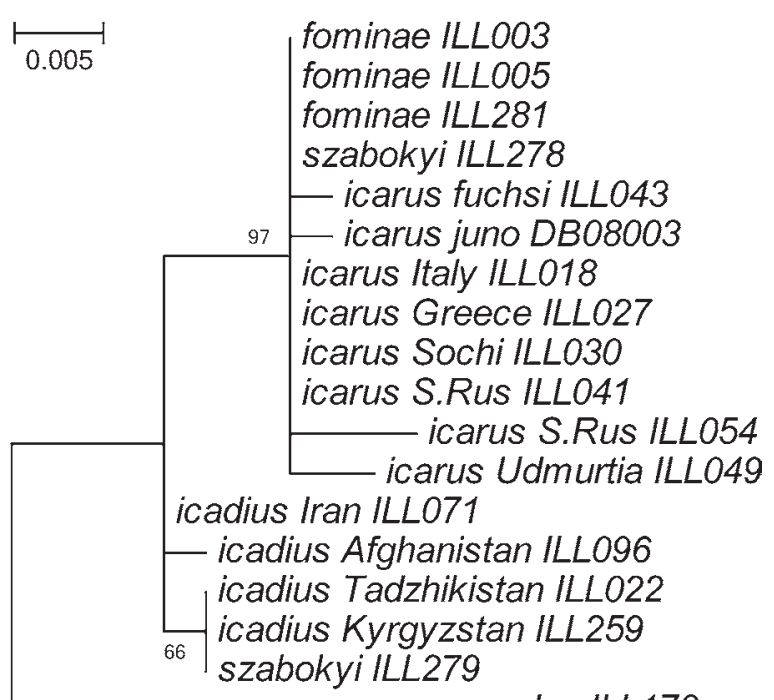

Fig. 7. Polyommatus spp.: ME-cladograms for ITS2 DNA sequences

Рис. 7. Polyommatus spp.: кладограмма для ITS2 ДНК сиквенсов. 